\title{
Evaluation of Diuretic Activity of Methanol Crude Extract of Thymus serrulatus Leaves and its Solvent Fraction in Mice
}

\author{
Amelework Eshetu Melka ${ }^{1}$, Eyasu Makonnen ${ }^{1}$, Asfaw Debella ${ }^{2}$, Netsanet Fekadu ${ }^{2}$ and Bekesho Geleta ${ }^{2^{*}}$ \\ ${ }^{1}$ Department of Pharmacology, School of Medicine, College of Health Sciences, Addis Ababa University, Addis Ababa, Ethiopia \\ ${ }^{2}$ Directorate of Traditional and Modern Medicine Research, Ethiopian Public Health Institute, Addis Ababa, Ethiopia
}

"Corresponding author: Bekesho Geleta, Directorate of Traditional and Modern Medicine Research, Ethiopian Public Health Institute, Addis Ababa, Ethiopia, Tel: +251911091969; E-mail: bekeshog@gmail.com

Received date: August 30, 2016; Accepted date: September 28, 2016; Published date: October 05, 2016

Copyright: ( 2016 Eshetu A, et al. This is an open-access article distributed under the terms of the Creative Commons Attribution License, which permits unrestricted use, distribution and reproduction in any medium, provided the original author and source are credited.

\begin{abstract}
Background: Thymus serrulatus is an indigenous plant to Ethiopia and used widely in the treatment of many illnesses including renal diseases and hypertension. The present study was undertaken to investigate the diuretic activity of the $80 \%$ methanol crude extract and solvent fractions of $T$. serrulatus leaves in saline-loaded mice.

Methods: Swiss albino mice of either sex were divided into six groups (five animals in each group). The control group received normal saline $(25 \mathrm{ml} / \mathrm{kg})$ in $2 \%$ Tween 80 , the reference group received hydrochlorothiazide (10 mg/ $\mathrm{kg}$ ). Group-III to Group-XIV received the test substances at dose levels of $125,250,500$, and $1000 \mathrm{mg} / \mathrm{kg}$ orally. At the end of the 5th hour, urine was collected and the total volume of urine excreted by each animal was recorded. Concentration of urinary $\mathrm{Na}^{+}, \mathrm{K}^{+}$, and $\mathrm{Na}^{+} / \mathrm{K}^{+}$ratio were also determined. The acute toxicity test was conducted for the most active fraction of the crude extract.
\end{abstract}

Results: The findings demonstrated that the crude methanol extract of $T$. serrulatus leaves and its n-butanol fraction have significant $(\mathrm{P}<0.01)$ diuretic activity. The $\mathrm{n}$-butanol fraction, at the dose of $1000 \mathrm{mg} / \mathrm{kg}$, displayed a pronounced diuretic activity $(104.0 \%)$ which was greater than the reference drug. It also showed a good natriuretic activity (1.34). However, the chloroform fraction was observed to lack significant diuretic activity and effect on electrolyte excretion except at the highest test dose.

Conclusion: The present findings indicate that the crude methanol extract of the leaves of $T$. serrulatus as well as its n-butanol fraction has significant diuretic effect with increased concentration of urinary electrolytes in mice. Further studies, however, should be carried out to come up with possible mechanism/s of action and look for the active component responsible for the diuretic effect.

Keywords: Diuretic activity; Electrolyte excretion; Thymus serrulatus, Extract

\section{Introduction}

Diuretics, also commonly referred to as "water pills" are drugs that act on the kidney to aid the elimination of water and sodium from the body. When the kidneys excrete sodium ion, they excrete water along with it which results in a decreased blood volume and pressure on the walls of the arteries. These groups of drugs are used to treat several conditions, such as high blood pressure, heart failure, liver disease and certain types of kidney disease [1]. The mechanism by which diuretics block the reabsorption of ions and the site of action varies; they may act at the proximal tubule (carbonic anhydrase inhibitors), loop of Henle (loop diuretics), distal tubule (thiazide diuretics), collecting tubule (potassium sparing diuretics), or combination of these sites [2].

Thymus serrulatus also locally known as "tossign" is a muchbranched perennial shrub that grows in the highlands of Semien Shoa, Tigray and Wollo. It is one of the endemic species of thyme in Ethiopia $[3,4]$. The leaves of the plant are used as condiments and medicines in the Ethiopian folklore medicine [5]. Tea made from the fresh leaves of
T. serrulatus is consumed for the management of renal disorders and hypertension [6].

Thyme species are widely utilized around the world for their diuretic activity [7]. The leaf of T. schimperi, is also traditionally used for urinary retention and hypertension, and is reported to show a diuretic activity with increased ionic content of urine in rats [8]. Moreover, there is also scientific evidence that aqueous leaf extract of T. serrulatus possesses an in vitro vasodilatory activity on thoracic aorta of Guniea pigs [9]. Hitherto, no prior scientific reports exist concerning its diuretic activity; therefore the present study attempts to evaluate the diuretic potential of the crude methanol extract of $T$. serrulatus and its solvent fractions in mice.

\section{Materials and Methods}

\section{Experimental animals}

Swiss albino mice of either sex, age of 4-6 weeks and a weight range of 20-25 g were used for the study. All animals used for this study were bred in the animal breeding facility of the Ethiopian Public Institute (EPHI). An acclimatization period of a week was given for all animals before the experiments were carried out. The laboratory conditions 
were maintained on a 12 hours light/dark cycle, with an ambient temperature of $25^{\circ} \mathrm{C}$. All animals had free access to standard pellet diet and water and were treated humanely throughout the study period.

\section{Grouping and dosing}

The animals were divided into six groups, each group comprised of five mice. Group I received 2\% Tween-80 in normal saline (NS) (25 $\mathrm{ml} / \mathrm{kg}$ ) and served as a negative control, Group-II received the standard diuretic drug, hydrochlorothiazide (HCTZ) $(10 \mathrm{mg} / \mathrm{kg})$. Groups III to VI received the test substance, methanol crude extract at test doses of 125, 250, 500, and $1000 \mathrm{mg} / \mathrm{kg}$; group VII to X received the test substance, chloroform fraction of methanol crude extract; group XI to XIV received the test substance, n-butanol fraction of methanol crude extract orally using gavage.

\section{Chemicals}

Hydrochlorothiazide Tablets (Esidrex $25 \mathrm{mg}$, Novartis), Absolute methanol (TechnoPharmChem, India), n-butanol (Merck, Germany), Chloroform (Chromasolr, England) were used. All the chemicals were purchased from reliable sources and were of analytical grade.

\section{Plant material}

The leaves of $T$. serrulatus were collected from Debresina, a town located $190 \mathrm{~km}$ North of Addis Ababa. The plant was identified by a taxonomist, Dr. Dawit Abebe, at EPHI and a voucher specimen (No. TS-2103) was deposited at the herbarium of Traditional and Modern Medicine Research Directorate (TMMRD) of EPHI.

\section{Extraction}

Crude extract: Powdered leaves of $T$. serrulatus $(600 \mathrm{~g})$ were macerated with $750 \mathrm{ml}$ of $80 \%$ methanol for 72 hours at room temperature. The extract was then filtered through Whatmann filter paper No.1, and the marc was re-macerated twice using the same volume of solvent to exhaustively extract the plant material. The solvent was removed under reduced pressure using Rotavapor (Büchi, U.S.A) at $40^{\circ} \mathrm{C}$ to give a greenish-black colored sticky extract which was kept in a refrigerator until further use. The percentage yield was $8.37 \%$.

\section{Fractionation}

The crude extract ( $42 \mathrm{~g}$ ) was allowed to suspend in $50 \mathrm{ml}$ of warm water. The suspension was shaken in a separatory funnel with $50 \mathrm{ml}$ of chloroform. The mixture was allowed to settle and form layers from which the bottom layer (chloroform fraction) was collected in a vial. This was repeated three times where the hydroalcoholic residue was then shaken using the same volume of chloroform. The residue was then shaken with $50 \mathrm{ml}$ of $\mathrm{n}$-butanol in the same manner to obtain the n-butanol fraction (upper layer).The resulting fractions were oven dried at a temperature of $40^{\circ} \mathrm{C}$.

\section{Screening for diuretic activity}

All extracts were screened for their diuretic activity using the Kau method with some modification [10]. The animals were placed in a standard metabolic cage. Food and water were withdrawn 18 hours prior to the experiment. All extracts were dissolved in physiological saline solution to make the required concentrations and were administered orally.

The cumulative urine excreted was measured at the end of the 5th hour in all groups. The parameters taken were total urine volume, urinary concentration of $\mathrm{Na}^{+}$and $\mathrm{K}^{+}$. The volume of the urine excreted in 5th hour of the study by each group is expressed as the percent of the liquid (normal saline) administered giving rise to a measure of "urinary excretion" independent of group weight. The ratio of urinary excretion in the test group to urinary excretion in the control group is used as a measure of the diuretic index for the given dose of a drug [11]. As the diuretic index is prone to variability, a parameter known as Lipschitz value was calculated. To obtain Lipschitz value, the diuretic index of the test substance is compared to that of the standard drug in the test group.

\section{Urinary excretion $=\left(\mathrm{V}_{\mathrm{o}} / \mathrm{V}_{\mathrm{i}}\right) \times 100$}

Where, $V_{o}$ is Total urinary output and $V_{i}$ is Total volume of fluid administered.

Diuretic index $=\mathrm{V}_{\mathrm{t}} / \mathrm{V}_{\mathrm{c}}$

Where, $V_{t}$ is mean urine volume of test group and $V_{c}$ is mean urine volume of control group.

Lipschitz value $=\mathrm{V}_{\mathrm{t}} / \mathrm{V}_{\mathrm{r}}$

Where, $V_{t}$ is mean urine volume of test group and $V_{r}$ is mean urine volume of reference group.

$\mathrm{Na}^{+} / \mathrm{K}^{+}$ratio $=\mathrm{C}_{\mathrm{n}} / \mathrm{C}_{\mathrm{k}}$

Where, $\mathrm{C}_{\mathrm{n}}$ is the concentration of $\mathrm{Na}^{+}$in urine of a group and $\mathrm{C}_{\mathrm{k}}$ is the concentration of $\mathrm{K}^{+}$in urine of same group.

\section{Determination of urinary $\mathrm{Na}^{+}$and $\mathrm{K}^{+}$}

The urinary sodium and potassium concentration was determined with flame photometer using Instrumentation Laboratory model 243.

\section{Acute toxicity study}

Swiss albino mice of either sex weighing between 20-25 g were divided into two groups having six animals each. Before the day of the experiment, the animals were deprived of food for 18 hours, and water was given ad libitum. The control group received NS while the other group received a limit dose of $5000 \mathrm{mg} / \mathrm{kg}$ of the $\mathrm{n}$-butanol fraction of the $80 \%$ methanol crude extract orally. Immediately after dosing, the animals were observed continuously for 24 hours giving special attention to the first four hours for overt signs of morbidity and mortality. The animals were kept under observation for up to 14 days thereafter [12].

\section{Phytochemical screening}

All extracts used for the in vivo study were subjected to phytochemical screening following methods described by Trease and Evans [13].

The extracts along with negative controls were tested for the presence of alkaloids, saponins, polyphenols, flavonoids, terpenoids, anthraquinones, tannins, phytosterols, and glycosides as follows:

Alkaloids: One and half milliliter of $10 \% \mathrm{HCl}$ was added to $0.5 \mathrm{mg}$ of the extracts in a test tube. The mixture was heated for 20 minutes. It was then cooled and filtered. To $1 \mathrm{ml}$ of the filtrate 5 drops Mayers and 
Page 3 of 6

Dragendorff's reagents each were added. Formation of cream and orange colored precipitates respectively indicates the presence of alkaloids in the extracts.

Saponins: Froth test: An aqueous solution of $0.5 \mathrm{mg}$ of the extract in a test tube was vigorously shaken for 2 minutes. Foam which persisted for 30 minutes and doesn't disappear upon warming was taken as an indication of the presence of saponin in the extract.

Polyphenols (Phenolic compounds): Three drops of a mixture of 1 $\mathrm{ml} 1 \% \mathrm{FeCl}_{3}$ and $1 \% \mathrm{~K}_{3} \mathrm{Fe}(\mathrm{CN})_{6}$ each were added to $2 \mathrm{ml}$ of extracts. Formation of green or blue color was taken as an indication of the presence of polyphenols.

Flavonoids: To $2 \mathrm{ml}$ of aqueous solution of the extract 4 drops of $2 \%$ lead acetate solution was added. Development of yellow or orange color confirms the presence of flavonoids.

Terpenoids (Ketonic): One milliliter of 2, 4-dinitrophenylhydrazine solutions $(0.5 \mathrm{~g}$ dissolved in $100 \mathrm{ml}$ of $2 \mathrm{M} \mathrm{HCl})$ was added to $2 \mathrm{ml}$ aqueous solution of the extract. Formation of yellow-orange coloration indicates the presence of a ketonic terpenoids.

Anthraquinones: Borntrager's test: Five milliletr of the extract was dried and shaken with $3 \mathrm{ml}$ petroleum ether. The filtrate was added to 2 $\mathrm{ml}$ of a $25 \%$ ammonia solution. The mixture was shaken and formation of a red coloration was taken as an indication of the presence of free anthraquinones.

Tannins: Three drops of $5 \%$ ferric chloride solution was added to $1 \mathrm{ml}$ of the extract solution in water. A greenish or blue coloration or precipitation was taken as indication of the presence of tannins.

Phytosterols and Withanoids: Five drops of $3 \%$ vanillin in conc. $\mathrm{H}_{2} \mathrm{SO}_{4}$ was added to a concentrated chloroform solution of extracts. Formation of a rose or reddish brown color indicates the presence of anoids or phytosterols.

\section{Test for glycosides (Keller-Killiani Test)}

To $0.5 \mathrm{~g}$ of each extract suspended in $5 \mathrm{ml}$ water, $2 \mathrm{ml}$ of glacial acetic acid containing one drop of ferric chloride hexahydrate $\left(\mathrm{FeCl}_{3} \cdot 6 \mathrm{H}_{2} \mathrm{O}\right)$ solution was added. This was mixed with $1 \mathrm{ml}$ of concentrated sulfuric acid and observed for a brown ring at the interface or a violet ring below the brown ring; alternatively acetic acid was added and observed for a greenish ring above the brown ring which gradually spread throughout this layer.

\section{Statistical Analysis}

Results are expressed as mean \pm standard error of mean. Statistical analysis was performed using the unpaired student's t- test and $\mathrm{P}<0.05$ was considered significant.

\section{Results}

\section{Urine output}

As shown in Table 1, the $80 \%$ methanol crude extract of $T$. serrulatus increased urine volume significantly at all test doses. The lowest and the highest urinary excretion were observed at a dose of 125 $\mathrm{mg} / \mathrm{kg}$ and $500 \mathrm{mg} / \mathrm{kg}$ with a diuretic index of 1.13 and 1.60 , respectively. The extract has a diuretic activity of about $88 \%$ at 500 $\mathrm{mg} / \mathrm{kg}$.

\begin{tabular}{|l|l|l|l|l|}
\hline Group & $\begin{array}{l}\text { Cumulative } \\
\text { volume of } \\
\text { urine }(\mathbf{m l})\end{array}$ & $\begin{array}{l}\text { Urinary } \\
\text { excretion } \\
\left(\mathbf{V}_{\mathrm{o}} / \mathbf{V}_{\mathrm{i}}\right) \mathbf{x} \mathbf{1 0 0}\end{array}$ & $\begin{array}{l}\text { Diuretic } \\
\text { index }\left(\mathbf{V}_{\mathrm{t}} / \mathbf{V}_{\mathrm{c}}\right)\end{array}$ & $\begin{array}{l}\text { Lipschitz } \\
\text { Value } \\
\mathbf{V}_{\mathrm{t}} / \mathbf{V}_{\mathrm{r}}\end{array}$ \\
\hline $\begin{array}{l}\text { Control }(2 \% \\
\text { Tween-80 in NS) }\end{array}$ & $3.75 \pm 0.41$ & 75 & - & - \\
\hline $\begin{array}{l}\text { Hydrochlorothiaz } \\
\text { ide }(10 \mathrm{mg} / \mathrm{kg})\end{array}$ & $6.75 \pm 0.91^{* * *}$ & 135 & 1.8 & - \\
\hline Ts-125 mg/kg & $4.25 \pm 0.37^{*}$ & 85 & 1.13 & 0.62 \\
\hline Ts-250 mg/kg & $4.75 \pm 0.56^{*}$ & 95 & 1.27 & 0.7 \\
\hline Ts-500 mg/kg & $6.0 \pm 0.82^{* *}$ & 120 & 1.6 & 0.88 \\
\hline Ts-1000 mg/kg & $5.5 \pm 0.69^{* *}$ & 110 & 1.47 & 0.81 \\
\hline
\end{tabular}

Note: Cumulative values are expressed as Mean \pm S.E.M $(n=5) ;{ }^{*} P<0.05$; ${ }^{* *} \mathrm{P}<0.01 ;{ }^{* *} \mathrm{P}<0.001$; Ts-T. serrulatus; NS-Normal Saline

Table 1: Effects of the $80 \%$ methanol crude extract of T. serrulatus on urine volume of normal mice.

The chloroform fraction of the $80 \%$ methanol crude extract as shown in Table 2 failed to show increased urinary output at 125, 250 and $500 \mathrm{mg} / \mathrm{kg}$. However, significant increase in urine volume occurred at $1000 \mathrm{mg} / \mathrm{kg}(\mathrm{P}<0.01)$ indicating a $92 \%$ diuretic activity as compared to the standard drug.

\begin{tabular}{|l|l|l|l|l|}
\hline \multicolumn{1}{|c|}{ Group } & \multicolumn{1}{|c|}{$\begin{array}{c}\text { Cumulative } \\
\text { volume of urine } \\
(\mathbf{m l})\end{array}$} & $\begin{array}{c}\text { Urinary } \\
\text { excretion } \\
\left(\mathbf{V}_{\mathrm{o}} / \mathbf{V}_{\mathrm{i}}\right) \mathbf{x} \mathbf{1 0 0}\end{array}$ & $\begin{array}{c}\text { Diuretic } \\
\text { index }\left(\mathbf{V}_{\mathrm{t}} / \mathbf{1}\right. \\
\left.\mathbf{V}_{\mathrm{c}}\right)\end{array}$ & $\begin{array}{c}\text { Lipschitz } \\
\text { Value } \\
\mathbf{V}_{\mathrm{t}} / \mathbf{V}_{\mathrm{r}}\end{array}$ \\
\hline $\begin{array}{l}\text { Control } \\
\text { Tween-80 in NS) }\end{array}$ & $4.75 \pm 0.67$ & 95 & - & - \\
\hline $\begin{array}{l}\text { Hydrochlorothiazid } \\
\text { e }(10 \mathrm{mg} / \mathrm{kg})\end{array}$ & $7.0 \pm 1.01^{*}$ & 140 & 1.47 & - \\
\hline Ts-125 mg/kg & $5.0 \pm 0.31$ & 100 & 1.05 & 0.71 \\
\hline Ts-250 mg/kg & $4.75 \pm 0.77$ & 110 & 1.16 & 0.67 \\
\hline Ts-500 mg/kg & $4.25 \pm 0.27$ & 85 & 0.89 & 0.6 \\
\hline Ts-1000 mg/Kg & $6.50 \pm 1.27^{*}$ & 130 & 1.37 & 0.92 \\
\hline
\end{tabular}

Note: Cumulative values are expressed as Mean \pm S.E.M for $n=5 ;{ }^{*} P<0.05$; ${ }^{* *} \mathrm{P}<0.01$; ${ }^{* *} \mathrm{P}<0.001$; Ts- $T$. serrulatus; NS-Normal Saline

Table 2: Effect of the chloroform fraction of the $80 \%$ methanol crude extract of T. serrulatus on urine volume in mice.

Unlike the chloroform fraction, the n-butanol fraction of the $80 \%$ methanol crude extract of $T$. serrulatus increased urine volume significantly at all doses (Table 3$)$. The highest diuretic index $(\mathrm{P}<0.01)$ was evident at $1000 \mathrm{mg} / \mathrm{kg}$ which was even greater than that of the HCTZ. The fraction at $500 \mathrm{mg} / \mathrm{kg}$ also displayed a comparable diuretic activity with the standard drug though less than the one observed with the highest dose. The least urinary excretion observed for this fraction was at $250 \mathrm{mg} / \mathrm{kg}$. 
Citation: Melka AE, Makonnen E, Debella A, Fekadu N, Geleta B (2016) Evaluation of Diuretic Activity of Methanol Crude Extract of Thymus serrulatus Leaves and its Solvent Fraction in Mice. Biol Med (Aligarh) 8: 347. doi:10.4172/0974-8369.1000347

Page 4 of 6

\begin{tabular}{|c|c|c|c|c|}
\hline Group & $\begin{array}{l}\text { Cumulative } \\
\text { volume of } \\
\text { urine (ml) }\end{array}$ & $\begin{array}{c}\text { Urinary } \\
\text { excretion } \\
\left(V_{o} / V_{i}\right) \times 100\end{array}$ & $\begin{array}{l}\text { Diuretic } \\
\text { index } \\
\left(\mathbf{V}_{\mathrm{t}} / \mathbf{V}_{\mathrm{c}}\right)\end{array}$ & $\begin{array}{l}\text { Lipschitz } \\
\text { Value } \\
\mathbf{V}_{\mathrm{t}} / \mathbf{V}_{\mathrm{r}}\end{array}$ \\
\hline Control (NS) & $3.5 \pm 0.12$ & 70 & - & - \\
\hline $\begin{array}{l}\text { Hydrochlorothiazide } \\
(10 \mathrm{mg} / \mathrm{kg})\end{array}$ & $5.75 \pm 0.33^{\star \star}$ & 115 & 1.64 & - \\
\hline $\mathrm{Ts}-125 \mathrm{mg} / \mathrm{kg}$ & $5.2 \pm 0.2^{*}$ & 104 & 1.49 & 0.9 \\
\hline $\mathrm{Ts}-250 \mathrm{mg} / \mathrm{kg}$ & $4.0 \pm 0.74^{*}$ & 80 & 1.14 & 0.69 \\
\hline Ts-500 mg/kg & $5.5 \pm 0.85^{\star *}$ & 110 & 1.57 & 0.95 \\
\hline Ts-1000 mg/kg & $6.0 \pm 1.2^{\star *}$ & 120 & 1.71 & 1.04 \\
\hline
\end{tabular}

Table 3: Effect of the n-butanol fraction of the $80 \%$ methanol crude extract of T. serrulatus on urine volume in mice.

\section{Electrolyte excretion}

Table 4 shows that the $80 \%$ methanol crude extract of T. serrulatus induced significant increase in urinary excretion of both $\mathrm{Na}^{+}$and $\mathrm{K}^{+}$. The extract showed the highest natriuresis at $500 \mathrm{mg} / \mathrm{kg}(\mathrm{P}<0.001)$, and the least was observed at $125 \mathrm{mg} / \mathrm{kg}$. Significant kaliuresis was observed at $250 \mathrm{mg} / \mathrm{kg}(\mathrm{P}<0.01), 500 \mathrm{mg} / \mathrm{kg}(\mathrm{P}<0.05)$ and $1000 \mathrm{mg} / \mathrm{kg}$ $(\mathrm{P}<0.01)$.

\begin{tabular}{|c|c|c|c|}
\hline \multirow{2}{*}{ Group } & \multicolumn{2}{|c|}{ Electrolyte concentration (MEq/I) } & \multirow[t]{2}{*}{$\mathrm{Na}^{+} / \mathrm{K}^{+}$} \\
\hline & $\mathrm{Na}^{+}$ & $\mathbf{K}^{+}$ & \\
\hline $\begin{array}{l}\text { Control ( } 2 \% \text { Tween- } 80 \\
\text { in NS) }\end{array}$ & $74.2 \pm 1.12$ & $47.5 \pm 1.11$ & 1.56 \\
\hline $\begin{array}{l}\text { Hydrochlorothiazide } \\
(10 \mathrm{mg} / \mathrm{kg})\end{array}$ & $112.7 \pm 1.8^{* * *}$ & $73.9 \pm 1.38^{*}$ & 1.52 \\
\hline $\mathrm{Ts}-125 \mathrm{mg} / \mathrm{kg}$ & $85.3 \pm 1.32$ & $50.4 \pm 1.09$ & 1.69 \\
\hline Ts-250 mg/kg & $101.2 \pm 1.37^{\star \star}$ & $69.1 \pm 1.46^{* *}$ & 1.46 \\
\hline Ts-500 mg/kg & $110.7 \pm 1.53^{\star \star *}$ & $57.2 \pm 1.16^{*}$ & 1.93 \\
\hline Ts-1000 mg/kg & $91.2 \pm 1.02^{* *}$ & $63.1 \pm 1.25^{\star *}$ & 1.44 \\
\hline
\end{tabular}

Table 4: Effect of the $80 \%$ methanol crude extract of T. serrulatus on electrolyte excretion in mice.

The chloroform fraction of the crude extract didn't cause significant urinary excretion of both sodium and potassium ion as shown in Table 5. However, the extract showed significant kaliuresis only at 1000 $\mathrm{mg} / \mathrm{kg}(\mathrm{P}<0.05)$.

As it shown in Table 6, the n-butanol fraction of the $80 \%$ methanol extract of $T$. serrulatus showed a dose- dependent increase in the urinary excretion of $\mathrm{Na}^{+}$and $\mathrm{K}^{+}$. The highest natriuresis and kaliuresis were observed at the dose of $1000 \mathrm{mg} / \mathrm{kg} \quad(\mathrm{P}<0.001$ and $\mathrm{P}<0.01$, respectively).

\begin{tabular}{|c|c|c|c|}
\hline \multirow{2}{*}{ Group } & \multicolumn{2}{|c|}{ Electrolyte concentration (MEq/l) } & \multirow[t]{2}{*}{$\mathrm{Na}^{+} / \mathrm{K}^{+}$} \\
\hline & $\mathrm{Na}^{+}$ & $\mathbf{K}^{+}$ & \\
\hline $\begin{array}{l}\text { Control ( } 2 \% \text { Tween- } 80 \text { in } \\
\text { NS) }\end{array}$ & $81.2 \pm 0.97$ & $53.71 \pm 1.21$ & 1.51 \\
\hline $\begin{array}{l}\text { Hydrochlorothiazide } \quad(10 \\
\mathrm{mg} / \mathrm{kg})\end{array}$ & $117.7 \pm 1.83^{* *}$ & $60.5 \pm 0.87^{*}$ & 1.94 \\
\hline Ts-125 mg/kg & $82.6 \pm 1.09$ & $51.2 \pm 0.62$ & 1.61 \\
\hline $\mathrm{Ts}-250 \mathrm{mg} / \mathrm{kg}$ & $83.2 \pm 0.89$ & $56.7 \pm 0.67$ & 1.46 \\
\hline $\mathrm{Ts}-500 \mathrm{mg} / \mathrm{kg}$ & $72.3 \pm 0.52$ & $49.2 \pm 0.38$ & 1.46 \\
\hline $\mathrm{Ts}-1000 \mathrm{mg} / \mathrm{kg}$ & $81.9 \pm 1.45$ & $54.8 \pm 1.81^{*}$ & 1.49 \\
\hline
\end{tabular}

Note: Cumulative values are expressed as Mean \pm S.E.M for $n=5 ;{ }^{*} P<0.05$; ${ }^{* \star} \mathrm{P}<0.01 ;{ }^{* \star *} \mathrm{P}<0.001$; Ts-T. serrulatus; NS-Normal Saline

Table 5: Effect of the chloroform fraction of $80 \%$ methanol extract of $T$. serrulatus on electrolyte excretion in mice.

\begin{tabular}{|c|c|c|c|c|}
\hline \multirow{2}{*}{ Group } & \multirow{2}{*}{$\begin{array}{c}\text { Dose } \\
\text { (mg/kg) }\end{array}$} & \multicolumn{2}{|c|}{$\begin{array}{l}\text { Electrolyte concentration } \\
\text { (MEq/l) }\end{array}$} & \multirow[t]{2}{*}{$\mathrm{Na}^{+} / \mathrm{K}^{+}$} \\
\hline & & $\mathrm{Na}^{+}$ & $\mathbf{K}^{+}$ & \\
\hline $\begin{array}{l}\text { Control ( } 2 \% \text { Tween- } 80 \\
\text { in NS) }\end{array}$ & - & $65.17 \pm 0.89$ & $58.1 \pm 0.67$ & 1.12 \\
\hline $\begin{array}{l}\text { Hydrochlorothiazide } \\
(10 \mathrm{mg} / \mathrm{kg})\end{array}$ & 10 & $\begin{array}{l}120.5 \\
1.71^{* * *}\end{array}$ & $66.3 \pm 1.12^{*}$ & 1.81 \\
\hline $\mathrm{Ts}-125 \mathrm{mg} / \mathrm{kg}$ & 125 & $72.2 \pm 1.25^{*}$ & $69.2 \pm 1.08^{*}$ & 1.04 \\
\hline $\mathrm{Ts}-250 \mathrm{mg} / \mathrm{kg}$ & 250 & $80.6 \pm 1.18^{*}$ & $67.9 \pm 0.91^{*}$ & 1.19 \\
\hline $\mathrm{Ts}-500 \mathrm{mg} / \mathrm{kg}$ & 500 & $98.4 \pm 1.86^{\star *}$ & $81.7 \pm 1.64^{\star *}$ & 1.2 \\
\hline Ts-1000 mg/kg & 1000 & $\begin{array}{l}115.9 \\
2.18^{* \star *}\end{array}$ & $86.2 \pm 1.78^{* *}$ & 1.34 \\
\hline
\end{tabular}

Note: Cumulative values are expressed as Mean \pm S.E.M for $n=5 ;{ }^{*} P<0.05$; ${ }^{* \star} \mathrm{P}<0.01 ;{ }^{* \star *} \mathrm{P}<0.001$; Ts- T. serrulatus; NS-Normal Saline

Table 6: Effect of the n-butanol fraction of $80 \%$ methanol extract of $T$. serrulatus on electrolyte excretion in mice.

\section{Acute toxicity test}

After administration of the oral limit dose of $5 \mathrm{~g} / \mathrm{Kg}$ of $\mathrm{n}$-butanol fractions of the crude methanol leaf extract of T. serrulatus all animals didn't show any overt sign of behavioral abnormality as well as morbidity during the observation period. Additionally, no mortality was observed during the same period which indicates that the $\mathrm{LD}_{50}$ of the fraction is greater than the limit dose employed here.

\section{Phytochemical screening}

Basic investigations of the extracts for their major phytocompounds is vital as the active principles of many drugs are these secondary metabolites found in plants. The various phytochemical screening tests performed on the crude extracts and solvent fractions Thymus serrulatus leaves revealed the presence of different secondary metabolites (Table 7). 
Page 5 of 6

\begin{tabular}{|l|l|l|l|l|l|l|l|l|l|}
\hline \multicolumn{1}{|c|}{ Type of extract } & Alkaloids & Saponins & Polyphenols & Flavonoids & Terpenoids & Anthraquinones & Tannins & Phytosterols & $\begin{array}{c}\text { Cardiac } \\
\text { glycosides }\end{array}$ \\
\hline Aqueous crude & + & + & + & - & - & - & + & + \\
\hline $\begin{array}{l}\text { Dichloromethane } \\
\text { fraction }\end{array}$ & - & + & - & + & - & - & + & + \\
\hline n-butanol fraction & + & + & + & - & - & - & + & + & - \\
\hline $\begin{array}{l}\text { Negative control } \\
\text { (vehicle) }\end{array}$ & - & - & - & - & - & - & - & - & - \\
\hline Note: +: present; -: absent & & & & & & & & - \\
\hline
\end{tabular}

Table 7: Phytochemical screening of aqueous crude extracts and solvent fractions of Thymus serrulatus leaves.

\section{Discussion}

Diuretics are substances that promote production of urine and elimination of ions such as sodium from the body. Despite their use in the treatment of edematous conditions they are associated with adverse effects such as hypovolemia, hypokalemia, hyperkalemia, hyponatremia, metabolic alkalosis, metabolic acidosis and hyperuricemia [14]. There is growing attention towards the use of medicines of herbal origins to combat a range of diseases. Numerous studies now exist affirming diuretic effects of traditional medicines [15]. The main advantage of using plant based diuretics is that they exhibit less adverse effects as compared to conventional diuretics available in the market. This property could allow their use as add-on therapy to improve tolerance to more potent drugs [16].

Scientific validation of these plants is a key component in the search for alternative plant based diuretics. In the present study, the diuretic effect of orally administered methanol extract of the leaves of $T$. serrulatus and its solvent fractions were evaluated in saline loaded mice at different test doses. The diuretic activities were compared with that of hydrochlorothiazide, a widely used diuretic in clinical practice. The methanol crude extract and its $\mathrm{n}$ - butanol fraction showed a significant urinary output as well as increase in ionic excretion. The diuretic potential of any substance is considered to be good if the diuretic index values are greater than 1.50 , moderate if the values are between 1.00 and 1.50 , mild if the values lie between 0.72 and 1.00 and nil if the value is $<0.72$ [17]. Accordingly, the $n$-butanol fraction has a "good" diuretic potential with a diuretic index of 1.54 and 1.71 at doses of $500 \mathrm{mg} / \mathrm{kg}$ and $1000 \mathrm{mg} / \mathrm{kg}$, respectively. The crude methanol extracts at all test doses as well as its chloroform fraction at the highest test dose elicited a "moderate" diuretic activity.

Unlike the crude extract and its n-butanol fraction, the chloroform fraction increased urine output at only the highest dose employed and failed to show appreciable electrolyte excretion. The observed difference in pharmacological response might be due to differential distribution of active phytoconsituents in the extract as well as its fractions. $\mathrm{Na}^{+} / \mathrm{K}^{+}$appears to be translatable biomarker of mineralocorticoid receptor (MR) antagonism following administration of single or multiple doses of compounds where in MR blockade causes an increase in urinary $\mathrm{Na}^{+} / \mathrm{K}^{+}$in rats [18]. $\mathrm{Na}^{+} / \mathrm{K}^{+}$is also an important indicator of natriuresis as sodium is considered an important external factor responsible for primary hypertension as well as water retention [16]. Beside serving as an indicator of a good natriuretic activity, a $\mathrm{Na}^{+} / \mathrm{K}^{+}$ratio of $>2$ also shows the ability of the test substance to excrete more large sodium ion than potassium ion which is a very essential quality for a good diuretic [19]. Whereas values $>10$ indicate a potassium sparing activity which was not seen in all test substances including the thiazide reference drug in this study.

The essential oil of the leaves of T. serrulatus were found to contain p-cymene (13\%), gamma-terpinene (13\%) and thymol (49\%) as major components [20]. Moreover, the phytochemical screening of the powdered dried leaves of $T$. serrulatus, revealed the presence of polyphenols, alkaloids, tannins, saponnins and phytosterols [21]. Phytoconstituents such as theobromine (alkaloid) [22], 2 (Aminomethyl) phenols [23] are known for their appreciable diuretic activity. While it is impossible to predict the phytoconstituents responsible for the observed diuretic activity of T. serrulatus, it can be suggested that its diverse content of polar phytoconstituents such as phenolic compounds might be responsible for the perceived response of the $\mathrm{n}$ - butanol fraction in mice.

\section{Conclusion}

In the light of the outcome of this study, it is reasonable to infer that the $80 \%$ methanol crude extract of the leaves of T. serrulatus and its nbutanol fraction have a diuretic spectrum similar to that of the standard diuretic, HCTZ, which correlates well with the traditional use of the plant in the treatment of renal disorders and hypertension. However, further studies have to be pursued to come up with the possible mechanism/s of diuretic action and the active component responsible for the diuretic action.

\section{Acknowledgements}

The authors are thankful for the financial support provided by School of Graduate Studies of Addis Ababa University and Ministry of Finance and Economic Development through Ethiopian Public Health Institute. We also would like to thank the staff of the Traditional and Modern Medicine Research Directorate for their assistance during the study.

\section{References}

1. Smith H (2014) Diuretics: a review for the pharmacist. SA Pharmaceutical Journal 81: 18-21.

2. Ives HE, Warnock DG (2004) Diuretic agents: Basic and clinical pharmacology (9thedn), Lange Basic Science, New York, pp: 241-59.

3. Grulich V (2013) Thymus serrulatus Hochst. Ex Benth. Thyme. 
Citation: Melka AE, Makonnen E, Debella A, Fekadu N, Geleta B (2016) Evaluation of Diuretic Activity of Methanol Crude Extract of Thymus serrulatus Leaves and its Solvent Fraction in Mice. Biol Med (Aligarh) 8: 347. doi:10.4172/0974-8369.1000347

Page 6 of 6

4. Hailemariam GA, Emire SA (2013) Antioxidant activity and preservative effect of thyme (Thymus schimperi R.). British Journal of Applied Science and Technology 3: 1311 .

5. Bekele E (2007) Study on actual situation of medicinal plants in Ethiopia.

6. Parvez N, Yadav S (2010) Ethnopharmacology of single herbal preparations of medicinal plant in Asendabo district, Jimma Ethiopia. Indian journal of traditional knowledge 9: 724-729.

7. Imelouane B, Amhamdi H, Wathelet JP, Ankit M, Khedid K (2009) Chemical composition of the essential oil of thyme (Thymus vulgaris) from Eastern Morocco. Int J Agric Bio 11: 11205-11208.

8. Haji H, Makonnen E, Debella A, Geleta B (2016) Evaluation of Diuretic and Antihypertensive Activity of Leaf Extracts of Thymus schimperi in Rats. British Journal of Pharmacology and Toxicology 7: 1-8.

9. Geleta B, Eyasu M, Kamo S, Debella A, Mekonnen E, et al. (2015) In vitro vasodilatory effect of aqueous leaf extract of Thymus seruulatus on thoracic aorta of Guniea pigs. Asian Pacific Journal of Tropical Biomedicine 5: 15-18.

10. Kau ST, Keddie JR, Andrews D (1984) A method for screening diuretic agents in the rat. Journal of pharmacological methods 11: 67-75.

11. Vogel GH, Vogel WH, Scholkens BA, Sandow J, Muller G, et al. (2008) Drug Discovery and Evaluation (3rdedtn) Pharmacological Assays, p: 85.

12. OECD (2008) Guidelines for the testing of new chemicals revised draft guideline 423; acute oral toxicity.

13. Trease GE, Evans WC (1989) Pharmacognosy (13thedtn) Bailliere Tindall, London, pp: 135-250.

14. Ramkumar GG, Parthiban P, Kanakavalli K, Prabakaran R, Vanan ST (2014) Diuretic herbs on siddha system of medicine - a review. International Journal of Research in Pharmaceutical and Nano Sciences 3: 43-49.
15. Snigdha M, Kumar SS, Sharmistha M, Lalit S, Tanuja S (2013) An Overview on Herbal Medicines as Diuretics with Scientific Evidence. Scholars Journal of Applied Medical Science 1: 209-214.

16. Wright CI, Van-Buren L, Kroner CI, Koning MMG (2007) Herbal medicines as diuretics: a review of the scientific evidence. Journal of Ethnopharmacology 114: 1-31.

17. Ashif M, Atif M, Amin MS, Zahari CD, Irshad A, et al. (2013) Diuretic activity of Trianthema portulacastrum crude extract in albino rats. Tropical Journal of Pharmaceutical Research 12: 967-972.

18. Eudy RJ, Sahasrabudhe V, Sweeney K, Tugnait M, King-Ahmad A, et al. (2011) The use of plasma aldosterone and urinary sodium to potassium ratio as translatable quantitative biomarkers of mineralocorticoid receptor antagonism. J Transl Med 9: 1.

19. Kumar BS, Swamy BV, Behara GM, Baidya M, Bilal S, et al. (2010) Diuretic Activity of the root of Homonoiaretusa (GRAH. EX WT.) MUELL. Pharmacologyonline 3: 276-284.

20. Asfaw N, Storesund HJ, Skattebol L, Tonnesen F, Aasen AJ (2000) Volatile oil constituents of two Thymus species from Ethiopia. Flavour and Fragrance Journal 15: 123-125.

21. Bekele A (2006) Evaluation of the spasmolytic activity and safety of T. serrulatusin laboratory animals.

22. Amirkia V, Heinrich M (2014) Alkaloids as drug leads-A predictive structural and biodiversity-based analysis. Phytochemistry Letters 10: 48-53.

23. Deana AA, Stokker GE, Schultz EM, Smith RL, Cragoe EJ, et al. (1983) 2(Aminomethyl) phenols, a new class of saluretic agents, 5. Fused-ring analogs. Journal of Medicinal Chemistry 26: 580-585. 